Case Report

\title{
A case report of metastatic giant sarcomatoid melanoma with BRAF V600E mutation: a complete response to targeted therapy
}

\author{
Matteo Torresetti ${ }^{1}$, Donatella Brancorsini ${ }^{2}$, Francesca Morgese $^{3}$, Valeria Cognigni ${ }^{3}$, \\ Alessandro Scalise $^{1}$, Rossana Berardi ${ }^{3}$ and Giovanni Di Benedetto ${ }^{1}$ \\ ${ }^{1}$ Clinic of Plastic and Reconstructive Surgery, Marche Polytechnic University Medical School, Ancona, Italy \\ ${ }^{2}$ Section of Pathological Anatomy, Marche Polytechnic University Medical School, Ancona, Italy \\ ${ }^{3}$ Clinic of Medical Oncology, Marche Polytechnic University Medical School, Ancona, Italy \\ Correspondence to: Matteo Torresetti, email: torresetti.matteo@gmail.com \\ Keywords: sarcomatoid melanoma; giant melanoma; BRAF mutation; targeted therapy; next-generation sequencing \\ Received: May 11, 2020 \\ Accepted: July 21, 2020 \\ Published: August 25, 2020
}

Copyright: Torresetti et al. This is an open-access article distributed under the terms of the Creative Commons Attribution License 3.0 (CC BY 3.0), which permits unrestricted use, distribution, and reproduction in any medium, provided the original author and source are credited.

\section{ABSTRACT}

Sarcomatoid melanoma is an extremely rare pattern of malignant melanoma, and only few cases have been described throughout the literature. We herein report a case of a patient with newly diagnosed, metastatic giant sarcomatoid melanoma of the arm. The patient underwent surgical removal of the huge mass, and NGS sequencing demonstrated BRAF V600E mutation.

In view of histological, immunohistochemical and molecular findings, a combined BRAF/MEK inhibitor (BRAF/MEK-i) therapy was prescribed as first line treatment. A complete response (over one year) to targeted therapy was obtained, and no adverse events have been reported. The patient maintained a full range of shoulder and elbow movements, and she is able to live independently and resume her daily activities. We therefore recommend that all patients with undifferentiated melanomas, sarcomatoid cutaneous malignancies or other mesenchymal tumours, should undergo BRAFV600E mutation testing.

\section{INTRODUCTION}

Giant cutaneous melanomas have rarely been described in the literature; the term "giant", although not formally defined, has been previously proposed for those lesions having a diameter larger than $10 \mathrm{~cm} \mathrm{[1].}$

Malignant melanomas show a wide variety of cytomorphological features, architectural patterns and stromal changes; hence may mimic several non-melanocytic tumours such as carcinomas, lymphomas, sarcomas, benign stromal tumours, plasmacytomas and germ cell tumours [2]. Malignant melanoma exhibiting a prominent sarcomatoid component, or sarcomatoid melanoma, is a further exceedingly rare pattern of melanoma with very few cases previously reported. Moreover, immunohistochemical evidence of melanocytic differentiation may be lacking.

Hence, it may pose several diagnostic conundrums as it encompasses a broad differential diagnosis of primary cutaneous pleomorphic spindle-cell neoplasms [3].
The exceptional rarity of these tumours and the existing scarce literature regarding its clinicopathologic behaviour, create significant diagnostic and therapeutic challenges. Therefore, the efficacy of targeted immunotherapies recently approved for melanoma is unknown.

We report our experience in treating a patient that had BRAFV600E mutant giant sarcomatoid melanoma of the arm, that was successfully treated with a combined BRAF/MEK inhibitor (BRAF/MEK-i) therapy after surgical removal of the tumour. We performed a literature search and did not identify any reported case of BRAF V600E mutant sarcomatoid melanoma patients treated with BRAF-i target therapy.

The authors believe that the present report represents a peculiar and extraordinary rare case both for its clinical presentation (including its exceptional size), diagnostic challenges and clinical behaviour. 


\section{CASE PRESENTATION}

A 70-year-old female was referred to the emergency department of our hospital for a large bleeding mass on the lateral aspect of her left arm measuring $19 \times 16$ $\mathrm{cm}$ (Figure 1). The lesion had been present for the last 10 months but the patient had no sought for medical attention, and it was finally reported by the woman for increasing fatigue and continuous bleeding of the lesion. Physical examination revealed a multilobed exophytic and vegetating mass, with several ulcerated, necrotic and pigmented areas. She had no sensory, motor or vascular deficits, and had a full range of shoulder and elbow movements. No axillary palpable lymphadenopathies were clinically detected. Blood test findings revealed severe iron deficiency anemia $(\mathrm{Hb} 7.0 \mathrm{gr} / \mathrm{dl})$ and hypoproitenemia (Albumin $1.5 \mathrm{gr} / \mathrm{dl}$ ) due to intermittent bleeding of the tumour and serum loss. Preoperative incisional biopsies of the lesion suspected a diagnosis of malignant melanoma, as immunohistochemical stains demonstrated the tumour cells to be negative for MART-1, HMB-45, LCDA and CD138, while they were positive for $\mathrm{S} 100$ protein and Vimentin.

An initial staging whole-body computed tomography (CT) scan showed several enlarged lymph nodes in the left groin, but no other evidence of distant metastases. These were biopsied and found to be benign. Therefore the patient underwent wide local excision of the mass with a $2 \mathrm{~cm}$ margin which included fascia and a cuff of the deltoid muscle bellies after a multidisciplinary tumour board consultation, and an immediate reconstruction by using a dermal substitute (Integra ${ }^{\circledR}$ Dermal Regeneration Template) was performed. Postoperative period was uneventful and the patient was discharged after 6 days. The patient was then followed in outpatient for wound management.

\section{Histological examination}

Grossly, the neoplasm was a huge pedunculated and extensively ulcerated mass.

Histological examination revealed a highly cellular neoplasm occupying dermis and hypodermis with a diffuse pattern of growth, showing a variable admixture of atypical epithelioid and spindle cells, with a predominance of the epithelioid component.

Tumour cells were relatively uniform with eosinophilic cytoplasm, nuclear pseudo-inclusions and prominent nucleoli (Figure 2A and 2B). Mitotic figures were readily found and tumour necrosis were frequently observed. There was no evidence of a junctional melanocytic component.

Immunohistochemical stains demonstrated strong but focal positivity for S-100 protein and SOX10 (Figure $2 \mathrm{C}$ and 2D) and negativity for melanocytic (Melan-A, HMB45), vascular (CD31, ERG) and myogenic markers (smooth muscle actin, desmin).

Subsequent testing by Ion Torrent next-generation sequencing (NGS) using the Cancer Hotspot Panel v2 (ThermoFisher Scientific, Life Technologies) revealed the presence of $\mathrm{p}$. V600E BRAF mutation involving the exon 15 , and a p. R80STOP mutation of CDKN2A in 53\% and
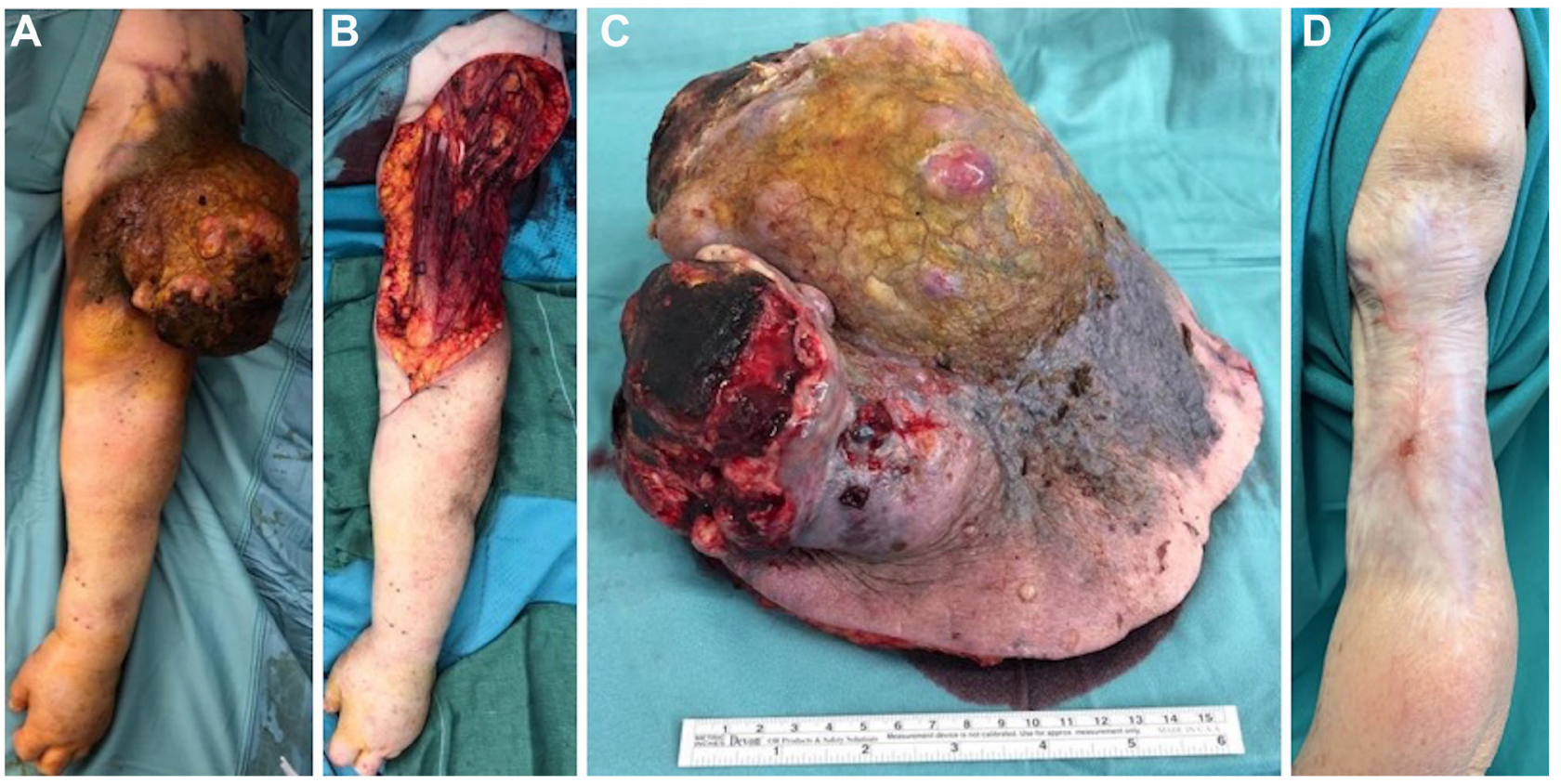

Figure 1: Initial presentation, surgical procedure and postoperative outcome. Preoperative picture of the huge tumor (A); intraoperative figure showing the defect after tumor excision $(\mathbf{B})$ and the sample sent to pathologist, measuring $19 \times 16 \mathrm{~cm}(\mathbf{C})$; one-year follow-up picture showing no recurrences of the disease and an acceptable aesthetic result (D). 
$85 \%$ of the analysed DNA, respectfully. The mutational analysis was performed by an outside institution.

Therefore, histological, immunohistochemical and molecular findings suggested the diagnosis of giant sarcomatoid melanoma.

Wound healing by secondary intention within 4 months was obtained. One year later, punch biopsies were performed for a hard-to-heal small wound on the left arm, but no signs of recurrent disease were detected.

\section{Combined target therapy}

Three months post-operatively, whole-body PET/ CT scan revealed a FDG-avid, presumptive pathological uptake in left lung (SUV max $=2.0$ ) and in left iliac wing $($ SUV max $=7$ ) (Figure 3). Considering the differential diagnosis, the stage and the presence of BRAF mutation, the patient appeared candidate to target therapy with BRAF-i in combination with MEK-i. This approach was shared by a multidisciplinary tumour board consultation. After fulfillment of normal echocardiography and optical coherence tomography scan, the patient started Dabrafenib $150 \mathrm{mg}$ bid and Trametinib $2 \mathrm{mg}$ od 4 months postoperatively. Target therapy was well tolerated. Imaging with whole-body CT scan after 4 months of combined target therapy revealed partial response in both sites of disease. In particular, there was a significant reduction in the lung metastasis $(0.3 \mathrm{~cm}$ vs. $1 \mathrm{~cm})$ and osteosclerosis of the left wing.

One year later, the whole-body CT scanning demonstrated a complete response of the disease with regression of the lung and bone metastasis (Figure 4). Currently, the treatment with Dabrafenib and Trametinib is ongoing at full dose with an optimal tolerance (completed $\mathrm{XV}$ cycle). Clinically, the patient maintained a full range of shoulder and elbow movements, and she is able to live independently and resume her daily activities. Figure 5 summarizes the whole medical history of the patient.

\section{DISCUSSION}

Sarcomatoid melanoma is an extremely rare pattern of malignant melanoma, and only few case reports or case series have been described. According to Erstine et al. [3], until 2017 had been reported only 3 cases of sarcomatoid melanoma. The first two reported cases exhibited a sarcomatoid phenotype in lymph node metastatic deposits, but not in the primary cutaneous tumour $[4,5]$, while Kiuru et al. [6] and Erstine et al. [3] reported the first cases of primary cutaneous sarcomatoid melanoma
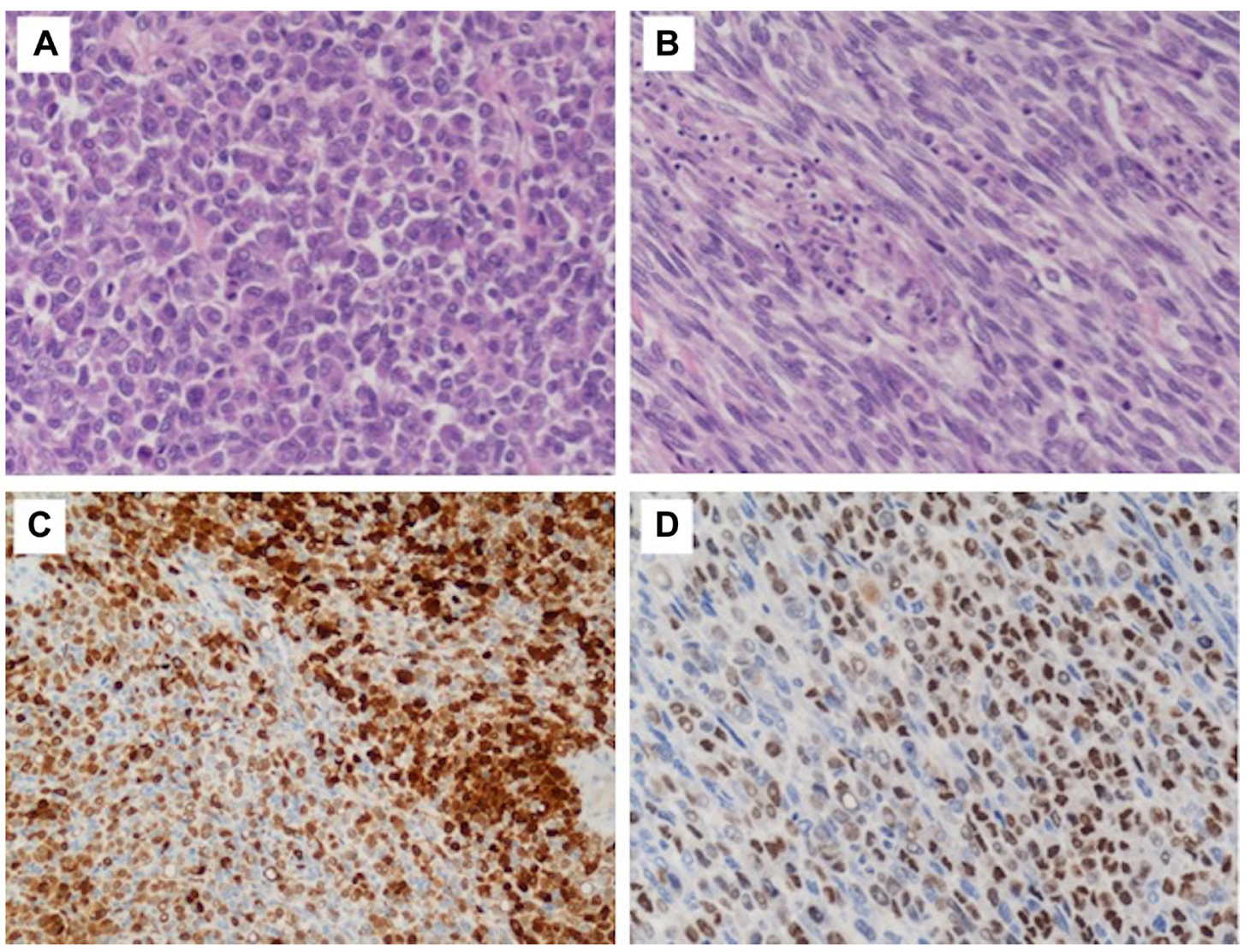

Figure 2: Histological findings of the tumor. High power view (H\&E, 20× magnification); tumor cells were relatively uniform with eosinophilic cytoplasm, nuclear pseudoinclusions and prominent nucleoli (A-B). Immunohistochemical staining demonstrated strong but focal positivity for S-100 protein (C) and SOX10 (D). 
described in the literature. Afterwards, two more cases of primary cutaneous sarcomatoid melanoma $[7,8]$ have been reported (Table 1).

To the best of our knowledge, this case represents the first giant primary cutaneous sarcomatoid melanoma described in the literature, and it is also one of the largest upper limb melanomas reported worldwide. By an accurate analysis of the reported cases, we can assert that no guidelines exist both for diagnostic and therapeutic management of this extremely rare tumour.

Hotspots mutations of the oncogenes BRAF and NRAS are the most common genetic alterations in cutaneous melanoma, and BRAF-targeted therapies demonstrated significant clinical benefits. Furthermore, several reports

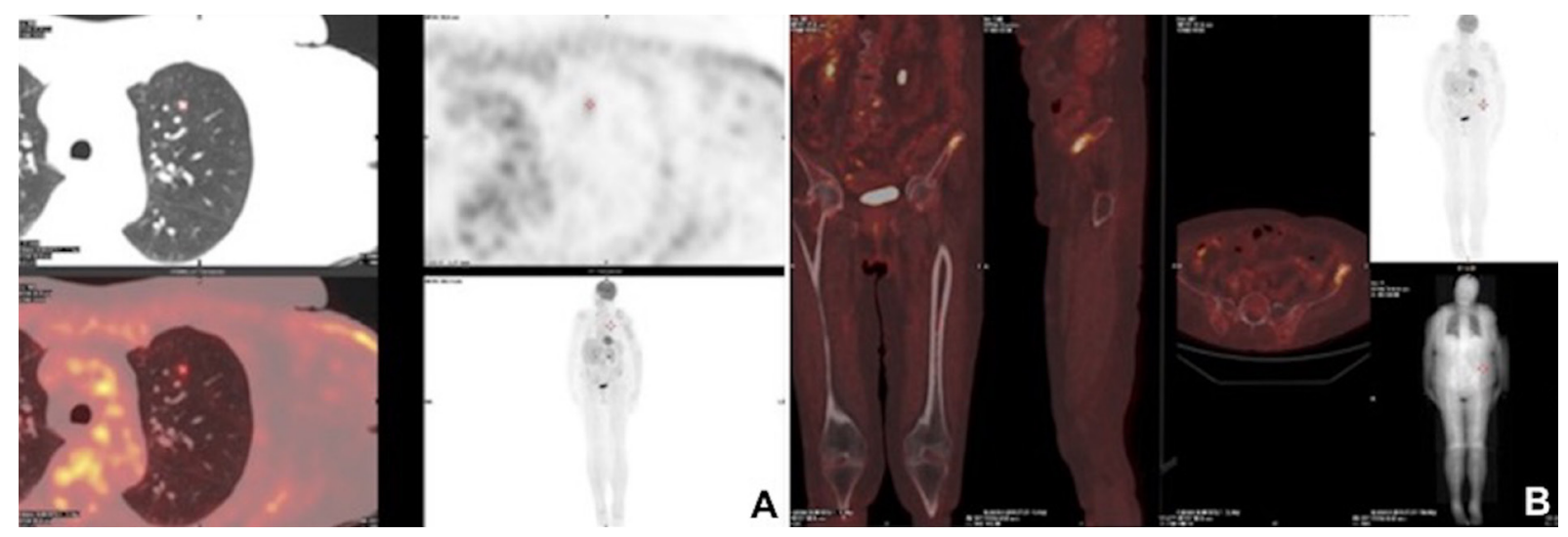

Figure 3: Postoperative radiological images. Three-months postoperative PET/CT scan showing a FDG-avid, presumptive pathological uptake in left lung (SUV max = 2.0) (A) and in left iliac wing (SUV $\max =7)(\mathbf{B})$.



Figure 4: Radiological images after combined targeted therapy. Computed tomography one year after BRAF/MEK-i therapy, showing a complete response of the disease with regression of the lung (A) and bone metastasis (B).



Figure 5: Timeline of patient's medical history. 
Table 1: Reported cases in the literature of sarcomatoid melanoma

\begin{tabular}{|c|c|c|c|c|c|c|c|}
\hline Author/Year & $\begin{array}{l}\text { No of cases/ } \\
\text { Site of } \\
\text { primary } \\
\text { tumour }\end{array}$ & $\begin{array}{l}\text { Age } \\
\text { (years)/ } \\
\text { Sex }\end{array}$ & $\begin{array}{l}\text { Size }(\mathrm{cm}) \text { of } \\
\text { primary tumour/ } \\
\text { Metastatic deposit }\end{array}$ & $\begin{array}{l}\text { Sarcomatoid phenotype/ } \\
\text { Molecular profile }\end{array}$ & $\begin{array}{l}\text { Nodal/Extranodal } \\
\text { diffusion }\end{array}$ & Therapy & Outcome \\
\hline $\begin{array}{l}\text { Banerjee S, } \\
\text { et al./1996 [4] }\end{array}$ & $\begin{array}{l}\text { 1/Epigastric } \\
\text { area }\end{array}$ & $54 / \mathrm{F}$ & $\mathrm{NA} / 4.5 \times 2.5 \times 2.0$ & $\begin{array}{l}\text { Lymph node metastatic } \\
\text { deposits (axilla)/NA }\end{array}$ & $\begin{array}{l}\text { Axillary, groin, } \\
\text { iliac lymph nodes/ } \\
\text { subcutaneous } \\
\text { metastatis }\end{array}$ & $\begin{array}{l}\text { Removal of } \\
\text { metastasis }+ \\
\text { groin dissection } \\
+ \text { decarbazine }+ \\
\text { interferon }\end{array}$ & $\begin{array}{l}\text { Alive ( } 9 \text { years } \\
\text { follow-up) }\end{array}$ \\
\hline $\begin{array}{l}\text { Kacerovska D, } \\
\text { et al./2009 [5] }\end{array}$ & $1 /$ Heel & $63 / \mathrm{M}$ & $\mathrm{NA} / 7 \times 6.5 \times 3.5$ & $\begin{array}{l}\text { Lymph node metastatic } \\
\text { deposits (groin)/NA }\end{array}$ & Groin metastasis & $\begin{array}{l}\text { Removal of } \\
\text { metastasis }\end{array}$ & $\begin{array}{l}\text { Died (multiple } \\
\text { liver and bone } \\
\text { metastases) }\end{array}$ \\
\hline $\begin{array}{l}\text { Kiuru M, } \\
\text { et al./2014 [6] }\end{array}$ & 1/Scalp & $66 / \mathrm{M}$ & NA & $\begin{array}{l}\text { Primary cutaneous SM/ } \\
\text { NA }\end{array}$ & NA & NA & NA \\
\hline \multirow[t]{2}{*}{$\begin{array}{l}\text { Erstine EM, } \\
\text { et al./2017 [3] }\end{array}$} & 2/Breast Heel & $65 / \mathrm{F}$ & $1,8 / 1$ & $\begin{array}{l}\text { Primary cutaneous } \\
\text { SM/BRAF mutational } \\
\text { analysis: negative }\end{array}$ & Axillary metastasis & $\begin{array}{l}\text { Wide local } \\
\text { excision }+ \\
\text { SLNB }+ \text { axillary } \\
\text { dissection }+ \\
\text { interferon }\end{array}$ & $\begin{array}{l}\text { PFS: } 9 \text { months } \\
\text { Died after } 19 \\
\text { months }\end{array}$ \\
\hline & & $62 / \mathrm{M}$ & NA & $\begin{array}{l}\text { Primary cutaneous } \\
\text { SM/BRAF mutational } \\
\text { analysis: negative }\end{array}$ & Groin metastasis & $\begin{array}{l}\text { Wide local } \\
\text { excision }+ \\
\text { SLNB + } \\
\text { superficial } \\
\text { inguinal } \\
\text { dissection }\end{array}$ & $\begin{array}{l}\text { PFS: } 25 \\
\text { months }\end{array}$ \\
\hline Fraga GR/2017 [7] & 1/Scalp & $75 / \mathrm{M}$ & $1,2 \times 1 / \mathrm{NA}$ & Primary cutaneous SM & NA & NA & NA \\
\hline $\begin{array}{l}\text { Lefferts JA, } \\
\text { et al./2020 [8] }\end{array}$ & 1/Thigh & $73 / \mathrm{M}$ & $6 \times 5 \times 3 / \mathrm{NA}$ & $\begin{array}{l}\text { Primary cutaneous SM/ } \\
\text { NRAS-BRAF mutational } \\
\text { analysis: positive (NRAS } \\
\text { p. Q61L) }\end{array}$ & Inguinal metastasis & Pembrolizumab & PFS: 3 months \\
\hline
\end{tabular}

Abbreviations: NA: not applicable; SM: sarcomatoid melanoma; SLNB: sentinel lymph node biopsy; PFS: progression free survival.

Table 2: Reported cases in the literature of BRAF mutant sarcoma patients treated with BRAFi target therapy

\begin{tabular}{|c|c|c|c|c|c|c|c|}
\hline Author/year & $\begin{array}{l}\text { Age } \\
(\text { years)/sex }\end{array}$ & Diagnosis & $\begin{array}{l}\text { Site of primary } \\
\text { tumour }\end{array}$ & Site of metastasis & Target therapy & Response & Outcome \\
\hline $\begin{array}{l}\text { Kaplan HG/2013 } \\
{[10]}\end{array}$ & $51 \mathrm{~F}$ & $\begin{array}{l}\text { Malignant } \\
\text { peripheral } \\
\text { nerve sarcoma }\end{array}$ & Right axilla & $\begin{array}{l}\text { Thoracic/abdominal } \\
\text { subcutaneous }+ \\
\text { local and adrenal } \\
\text { recurrence }\end{array}$ & $\begin{array}{l}\text { Vemurafenib as } \\
\text { second line of } \\
\text { treatment }\end{array}$ & $\begin{array}{l}\text { Partial } \\
\text { response } \\
\text { after } 1 \\
\text { month }\end{array}$ & Unknown \\
\hline $\begin{array}{l}\text { Idbaih A, } \\
\text { et al./2014 [11] }\end{array}$ & $40 \mathrm{M}$ & $\begin{array}{l}\text { Histiocytic } \\
\text { sarcoma }\end{array}$ & CNS & & $\begin{array}{l}\text { Vemurafenib } \\
\text { as first line of } \\
\text { treatment }\end{array}$ & $\begin{array}{l}\text { Partial } \\
\text { response }\end{array}$ & PFS: 4 months \\
\hline $\begin{array}{l}\text { Protsenko SA, } \\
\text { et al./2015 [12] }\end{array}$ & $46 \mathrm{M}$ & $\begin{array}{l}\text { Clear cell } \\
\text { sarcoma }\end{array}$ & Lumbar area & $\begin{array}{l}\text { Local recurrence, } \\
\text { bone and lung }\end{array}$ & $\begin{array}{l}\text { Vemurafenib as } \\
\text { second line of } \\
\text { treatment }\end{array}$ & $\begin{array}{l}\text { Complete } \\
\text { response } \\
\text { after } 8 \text { weeks }\end{array}$ & Unknown \\
\hline $\begin{array}{l}\text { Mitsis D, } \\
\text { et al./2015 [12] }\end{array}$ & $69 \mathrm{M}$ & $\begin{array}{l}\text { high-grade } \\
\text { spindle cell } \\
\text { STS }\end{array}$ & Abdomen-pelvis & Lung & $\begin{array}{l}\text { Dabrafenib and } \\
\text { trametinib as } \\
\text { second line of } \\
\text { treatment }\end{array}$ & $\begin{array}{l}\text { Partial } \\
\text { response } \\
\text { after } 6 \text { weeks }\end{array}$ & Unknown \\
\hline $\begin{array}{l}\text { Branco B, } \\
\text { et al./2019 [14] }\end{array}$ & $22 \mathrm{~F}$ & $\begin{array}{l}\text { Histiocytic } \\
\text { sarcoma }\end{array}$ & NA & $\begin{array}{l}\text { abdominal lymph- } \\
\text { nodes and liver }\end{array}$ & $\begin{array}{l}\text { Vemurafenib } \\
(+ \text { Gemcitabine }) \\
\text { as second line of } \\
\text { treatment }\end{array}$ & $\begin{array}{l}\text { Complete } \\
\text { response } \\
\text { after } 18 \\
\text { months }\end{array}$ & $\begin{array}{l}\text { Treatment ongoing at } \\
\text { time of submission }\end{array}$ \\
\hline $\begin{array}{l}\text { Watanabe S, } \\
\text { et al./2020 [15] }\end{array}$ & $23 \mathrm{~F}$ & $\begin{array}{l}\text { Synovial } \\
\text { sarcoma }\end{array}$ & $\begin{array}{l}\text { Superior } \\
\text { mediastinum }\end{array}$ & Local recurrence & $\begin{array}{l}\text { Dabrafenib }+ \\
\text { Trametinib as } \\
\text { second line of } \\
\text { treatment }\end{array}$ & $\begin{array}{l}\text { Complete } \\
\text { response at } 3 \\
\text { months after } \\
\text { starting }\end{array}$ & $\begin{array}{l}\text { PFS: } 7,5 \text { months } \\
\text { (NRAS mutation } \\
\text { as mechanism of } \\
\text { resistance) }\end{array}$ \\
\hline
\end{tabular}

Abbreviations: NA: not applicable; CNS: central nervous system; STS: soft tissue sarcoma; PFS: progression free survival. 
have anecdotally documented BRAF mutation in 1-9\% of all sarcomas as highlighted by Cipriani et al. [9], and the same authors suggested that BRAF mutational analysis should be considered in those patients with a spindle cell malignancy and a history of melanoma, as a positive result may indicate de-differentiated melanoma.

From a therapeutic perspective, when a target and its specific inhibitor exist, the target therapy shows high response rate, usually, independently of histotype [10-15] (Table 2).

Due to these findings, the proposal to perform BRAF mutational analysis in rare tumours such as sarcoma appeared a reasonable strategy for initiating appropriate clinical management. In previous reports, these mutations were rarely encountered in sarcomatoid melanoma, and only Lefferts et al. recently reported a somatic variant of NRAS p. Q61L revealed by NRAS-BRAF Mutation Assay in the sarcomatoid component [8]. Erstine et al. also performed BRAF mutational analysis of the tumour but no mutations were detected [3].

The present case reported the first exceptional therapeutic response to first-line combined BRAF and MEK-targeted therapy in a giant metastatic sarcomatoid melanoma harboring BRAF V600E mutation. This tumour was exceptionally responsive to targeted treatment, with a complete radiological and clinical response after a few months.

\section{CONCLUSIONS}

Our findings suggest that first line combined treatment with BRAF and MEK inhibitors can lead to dramatic tumour response in patients with $B R A F \mathrm{~V} 600 \mathrm{E}$ metastatic sarcomatoid melanoma. We therefore recommend that all patients with undifferentiated melanomas, sarcomatoid cutaneous malignancies or other mesenchymal tumours, should undergo BRAFV600E mutation testing, in order to guide the clinicians in the differential diagnosis, thus ensuring the most appropriate treatment for the patient.

\section{Consent of publication}

The patient provided written informed consent for surgery and use of pictures for academical and study purpose.

\section{ACKNOWLEDGMENTS}

We thank Dr. Antonina Parafioriti (Unit of Pathological Anatomy, Gaetano Pini-CTO Hospital, Milano, Italy) for her important contribution to molecular analysis.

We thank the "Skin Cancer Group" Collaborators of our Hospital for the multidisciplinary consultation of the presented case.

\section{CONFLICTS OF INTEREST}

The authors declare no conflicts of interest.

\section{REFERENCES}

1. Ching A, Gould L. Giant scalp melanoma: a case report and review of the literature. Eplasty. 2012; 12:e51. [PubMed]

2. Banerjee SS, Harris M. Morphological and immunophenotypic variations in malignant melanoma. Histopathology. 2000; 36:387-402. https://doi.org/10.1046/ j.1365-2559.2000.00894.x. [PubMed]

3. Erstine EM, Tetzlaff MT, Ko JS, Prieto VG, Cheah AL, Billings SD. Living on the Edge: Diagnosing Sarcomatoid Melanoma Using Histopathologic Cues at the Edge of a Dedifferentiated Tumour: A Report of 2 Cases and Review of the Literature. Am J Dermatopathol. 2017; 39:593598. https://doi.org/10.1097/DAD.0000000000000716. [PubMed]

4. Banerjee S, Bishop P, Nicholson C, Eyden BP. Malignant melanoma showing smooth muscle differentiation. J Clin Pathol. 1996; 49:950-951. https://doi.org/10.1136/ jcp.49.11.950. [PubMed]

5. Kacerovska D, Michal M, Kutzner H, Rychnovsky J, Kazakov DV. Metastatic desmoplastic malignant melanoma associated with low-grade myofibroblastic sarcoma. Am J Dermatopathol. 2009; 31:490-494. https://doi.org/10.1097/ DAD.0b013e31819afdaa. [PubMed]

6. Kiuru M, Mcdermott G, Berger M, Halpern AC, Busam KJ. Desmoplastic melanoma with sarcomatoid dedifferentiation. Am J Surg Pathol. 2014; 38:864-870. https://doi.org/10.1097/PAS.0000000000000201. [PubMed]

7. Fraga GR. Diagnosis of Sarcomatoid Melanoma by Surrogate Immunostains. Am J Dermatopathol. 2018; 40:304-305. https://doi.org/10.1097/DAD.0000000000000993. [PubMed]

8. Lefferts JA, Loehrer AP, Yan S, Green DC, Deharvengt SJ, LeBlanc RE. CD10 and p63 expression in a sarcomatoid undifferentiated melanoma: A cautionary (and molecularly annotated) tale. J Cutan Pathol. 2020; 47:541-547. https:// doi.org/10.1111/cup.13646. [PubMed]

9. Cipriani NA, Letovanec I, Hornicek FJ, Mullen JT, Duan Z, Borger DR, Nielsen GP. BRAF mutation in 'sarcomas': a possible method to detect de-differentiated melanomas. Histopathology. 2014; 64:639-646. https://doi.org/10.1111/ his.12305. [PubMed]

10. Kaplan HG. Vemurafenib treatment of BRAF V600Emutated malignant peripheral nerve sheath tumor. J Natl Compr Canc Netw. 2013; 11:1466-1470. https://doi. org/10.6004/jncen.2013.0173. [PubMed]

11. Idbaih A, Mokhtari K, Emile JF, Galanaud D, Belaid H, de Bernard S, Benameur N, Barlog VC, Psimaras D, Donadieu J, Carpentier C, Martin-Duverneuil N, Haroche $\mathrm{J}$, et al. Dramatic response of a BRAF V600E-mutated primary CNS histiocytic sarcoma to vemurafenib. 
Neurology. 2014; 83:1478-1480. https://doi.org/10.1212/ WNL.0000000000000880. [PubMed]

12. Protsenko SA, Semionova AI, Komarov YI, Aleksakhina $\mathrm{SN}$, Ivantsov AO, Iyevleva AG, Imyanitov EN. BRAFmutated clear cell sarcoma is sensitive to vemurafenib treatment. Invest New Drugs. 2015; 33:1136-1143. https:// doi.org/10.1007/s10637-015-0280-0. [PubMed]

13. Mitsis D, Opyrchal M, Zhao Y, Kane Iii JM, Cheney R, Salerno KE. Exceptional Clinical Response to BRAFTargeted Therapy in a Patient with Metastatic Sarcoma. Cureus. 2015; 7:e439. https://doi.org/10.7759/cureus.439. [PubMed]
14. Branco B, Comont T, Ysebaert L, Picard M, Laurent C, Oberic L. Targeted therapy of BRAF V600E-mutant histiocytic sarcoma: A case report and review of the literature. Eur J Haematol. 2019; 103:444-448. https://doi. org/10.1111/ejh.13303. [PubMed]

15. Watanabe S, Shimomura A, Kubo T, Sekimizu M, Seo T, Watanabe SI, Kawai A, Yamamoto N, Tamura K, Kohno $\mathrm{T}$, Ichikawa H, Yoshida A. BRAF V600E mutation is a potential therapeutic target for a small subset of synovial sarcoma. Mod Pathol. 2020 Apr 1. https://doi.org/10.1038/ $\underline{\text { s41379-020-0530-3. Epub ahead of print. [PubMed] }}$ 